\title{
Argumentative and narrative written task performance: Differential effects of critical thinking
}

Dabaghi, Azizollah

Department of English, University of Isfahan, Iran (dabaghi@fgn.ui.ac.ir)

Zabihi, Reza $\bigotimes$

Department of English, University of Isfahan, Iran (zabihi@hotmail.com)

Rezazadeh, Mohsen

Department of English, University of Isfahan, Iran (m1rezazadeh@gmail.com)

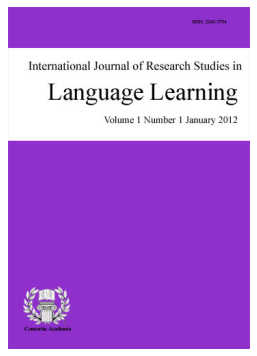

ISSN: 2243-7754 Online ISSN: 2243-7762

OPEN ACCESS

\section{Abstract}

This study compares the differential role of critical thinking in learners' performance on argumentative and narrative written tasks. The study involved the measurement of 70 upper-intermediate learners' critical thinking using the Watson-Glaser Critical Thinking Appraisal (WGCTA) as well as the elicitation of their performance on the written narrative and argumentative tasks. While the argumentative task required that learners write an argumentative essay giving their opinions concerning the effect of technology on human's life, the narrative task involved learners in narrating a story based on a picture as a visual cue. Concerning the narrative task, only a significant negative correlation was observed between drawing inferences and the two accuracy measures of the narrative task. With regards to the argumentative task, the correlation analysis showed negative relationships between the three measures of argumentative task fluency and students' score on the Drawing Inferences subscale. Results of the complexity measures revealed that the syntactic complexity of produced argumentations was affected by learners' ability to make deductions, interpreting evidence, and evaluating arguments. Finally, with regards to the accuracy of the performances, it was found that only Recognizing Assumptions had a significant, but negative, relationship with error-free clauses percentage and error-free T-unit percentage.

Keywords: critical thinking; Watson-Glaser; argumentative task; narrative task; CAF 


\section{Argumentative and narrative written task performance: Differential effects of critical thinking}

\section{Introduction}

In order to figure out why some learners of language are more fortunate than others in academic success, researchers have turned their attention towards individual differences. Such interest has accordingly spawned a number of recent studies on the topic (e.g., Conard, 2006; Farsides \& Woodfield, 2003; Labby, Lunenburg, \& Slate, 2012; Laidra, Pullmann, \& Allik, 2006; Naderi et al., 2009; Parker et al., 2004).

Paulo Freire (1970) and John Dewey (1916) are but two key figures who have sought democracy in education and have accordingly inspired many scholars, researchers, and practitioners who are ready to help learners have their voices heard in and out of the classroom. The 'banking' approach to education hinders learners from thinking critically by imposing on them a passive stance which makes them adaptive to the status-quo. In this line, the notion of 'banking education' has been denounced by the professionals of critical pedagogy who try their best to emancipate students from the confines of those classrooms wherein, due to the asymmetrical relationships between teacher and student, the teacher is traditionally supposed to transfer knowledge to students, while students are expected to get and conform to the information, whether right or wrong, without being enfranchised to criticize the authenticity of the knowledge being transferred. Lamentably, schools do not let the students take an active role in community life; nor do they try to make students effective social agents in society. Perhaps this is best summed up in Gatto's (2001) statement:

"School, as it was built, is an essential support system for a model of social engineering that condemns most people to be subordinate stones in a pyramid that narrows as it ascends to a terminal of control” (p. 13).

Many researchers have asserted the influential role of critical thinking in students' academic achievement (e.g., Birjandi \& Bagherkazemi, 2010; Fahim, Bagherkazemi, \& Alemi, 2010; McCutcheon, Apperson, Hanson, \& Wynn, 1992; Yeh \& Wu, 1992). Moreover, in the area of language learning, many scholars and researchers have considered critical pedagogy and critical language awareness to be essential concepts in both language learning and language teaching (Canagarajah, 1999; Norton \& Toohey, 2004; Pennycook, 1999, 2001; Ramanathan, 2002). Accordingly, it seems that language tasks which require greater elaboration and criticality on the part of learners might demand more instruction in critical thinking; therefore, critical thinking which simply refers to people's ability to explore, criticize, or advocate different ideas, to reason inductively and deductively, and to infer sound conclusions from ambiguous statements (Freeley \& Steinberg, 2000), should be the cornerstone of second or foreign language teaching classrooms, particularly when it comes to tasks which demand more critical awareness.

One of the domains wherein critical thinking might open up a pertinent line of investigation is the writing ability. Within the communicative paradigm of language education, the skill of writing enjoys a special status. That is to say, it is through writing that individuals can convey lots of messages to different readers. When it comes to the role of critical thinking, the question arises as to how different might be the role of this concept in learners' performance on various task types which in turn would require different levels of criticality on the part of writers. As far as justifying the role of critical thinking is concerned, argumentative written tasks, which demand that learners develop their own argument by bringing forth the relevant pieces of evidence as well as to assess arguments put forward by other people, seem to be quite relevant. In order to justify this role, the present study compares and contrasts the differential roles of critical thinking in learners' performance on argumentative and narrative written tasks. 


\section{Theoretical Framework}

In the following paragraphs, the researchers briefly review the theoretical and empirical findings pertaining to critical thinking as well as its applications in general education and language learning. Besides, they refer to the relevance of critical thinking to SLA written tasks, coming up with the hypothesis that different levels of critical thinking might have differential impacts on learners' performance on different written task types.

\subsection{Defining Critical Thinking}

In order to get to grips with the notion of 'critical thinking', we first need to clarify what this term mean. Critical thinking has been defined as the active, persistent, and careful consideration of any belief or supposed form of knowledge in the light of the grounds that support it and the further conclusions to which it tends (Dewey, 1933, p. 118). It comprises a number of skills such as, inter alia, the ability to (i) focus on the problem, (ii) uncover assumptions underlying a problem, (iii) reason inductively and deductively, and (iv) judge the validity and reliability of assumptions and sources of information (Pithers \& Soden, 2000). It is "our active, purposeful, and organized efforts to make sense of our world by carefully examining our thinking, and the thinking of others, in order to clarify and improve our understanding" (Chafee, 1988, p. 29). It also encompasses important factors such as analysis, evaluation, inference, interpretation, explanation and self-regulation (Facione, 2006).

Based on these and other explications of the term, several tests of measuring critical thinking have accordingly been designed by researchers (e.g., Facione, 1990a, 1990b; Ennis \& Millman, 1985; Ennis \& Weir, 1985; Norris \& Ennis, 1989; Norris \& King, 1984; Shipman, 1983; Ross \& Ross, 1976; Fraser, 1980; Sternberg \& Baron, 1985; Wagner, \& Harvey, 2003; Watson \& Glaser, 1980, 2006). These researchers have employed a cornucopia of ideas from other fields to broaden their perspectives. Whereas some tests of critical thinking such as Test on Appraising Observations, designed by Norris and King (1984), assess only one dimension of learners' critical thinking ability, other tests such as the Watson-Glaser Critical Thinking Appraisal (Watson \& Glaser, 1980) cover multiple critical thinking abilities. As one of the most reliable measures of critical thinking ability, WGCTA includes five subsections (Gadzella \& Baloglu, 2003; McKown, 1997), and several researchers have utilized it in their studies (e.g., Birjandi \& Bagherkazemi, 2010; Fahim et al., 2010; Ghaemi \& Taherian, 2011; Loftspring, 2006; McCutcheon et al., 1992).

\subsection{The Relevance of Critical Thinking to Language Learning Success}

In the area of education, there is a consensus among scholars and researchers on the necessity of raising students' critical awareness in schools and in the classroom, considering the fact that they have found positive relationships between this ability and students' academic success (e.g., Frisby, 1992; Giancarlo \& Facione, 2001; Jacobs, 1995; King, Wood, \& Mines, 1990; Kokinda, 1989; Mines, King, Hood, \& Wood, 1990; McCutcheon et al., 1992; Nelson, 1994; Tsui, 2002; Villavicencio, 2011; Yeh \& Wu, 1992). In one study, having utilized the California Critical Thinking Skills Test (CCTST), Jacobs (1995) explored the effect of critical thinking ability on university students' grades on the Student Aptitude Test (SAT). The results indicated that their scores on the CCTST were significantly related to students' level of verbal intelligence as measured by the SAT. In another study, Villavicencio (2011) made attempts at uncovering the nexus between engineering students' critical thinking ability and their achievement scores. He found that critical thinking had a positive correlation with students' final scores. Furthermore, Yeh and Wu (1992) examined the role of critical thinking in the academic achievement of elementary and secondary school students.

Having utilized the Cornell Critical Thinking (CCT) test for the measurement of critical thinking, they concluded that critical thinking scores significantly correlated with students' total achievement grades. Similarly, McCutcheon et al. (1992) studied the role of critical thinking abilities in the academic achievement of psychology students. The findings showed that two subscales of Watson-Glaser Critical Thinking Appraisal 
(WGCTA), i.e. the ability to draw valid inferences and the ability to weigh and interpret evidence, had a positive role to play in achievement grades. In another study, Kokinda (1989) utilized the Watson-Glaser Critical Thinking Appraisal in order to examine the relationship between critical thinking and academic achievement among nursing students; the results revealed a significant correlation between the scores obtained from this test and students' achievement scores. Unlike these studies, Azar (2010) found no significant relationship between students' critical thinking and their achievement levels.

In the case of language learning, especially learning English as a second or foreign language, where a mixture of historical, social, cultural, and political issues is involved, the importance of enhancing learners' critical thinking is even more visible, and needs to be seriously taken into consideration. Sadly, however, there is a shortage of research (e.g., Birjandi \& Bagherkazemi, 2010; Fahim et al., 2010; Ghaemi \& Taherian, 2011) to show the necessity of developing critical thinking in ELT classes. As a case in point, having utilized the Successful Iranian EFL Teacher Questionnaire (SIETQ) alongside WGCTA, Birjandi and Bagherkazemi (2010) studied the role of ELT teachers' critical thinking ability and their success in teaching. The results of their study revealed that 3 subscales of the Watson-Glaser Critical Thinking Appraisal, i.e. drawing inferences, interpreting evidence, and evaluating arguments could predict about half of teaching success.

Similarly, Ghaemi and Taherian (2011) found a significant relationship between EFL teachers' critical thinking and their professional success. In another study, Fahim et al. (2010) examined the relationship between advanced EFL learners' performance on the WGCTA and the reading module of TOEFL. They found out that the reading test scores and those on the WGCTA had a significant relationship. However, to our best knowledge, this relationship have not transcended beyond a cause and effect relationship between critical thinking and achievement, with achievement being measured by the results of a simple multiple-choice exam or indicated by learners' final exam grades; on the other hand, we believe, it is important to examine whether this skill might play any role in learners' performance on different authentic tasks, whereby learners are expected to produce something (oral or written) or comment on the value or merit of some piece of language-related work.

\subsection{The Relevance of Critical Thinking to L2 Writing Tasks}

Task Based Language Teaching (TBLT), as a new approach within the communicative framework, has highlighted the well-deserved attention on language teaching through various language tasks (Pica, Kanagy, \& Falodun, 1993; Skehan, 1998; Willis \& Willis, 1996) and has introduced a new avenue for research in ELT. A task is "an activity in which: meaning is primary; there is some relationship to the real world; task completion has some priority; and the assessment of task performance is in terms of task outcome" (Skehan, 1996, p. 38). However, the point which needs to be considered here is that the degree of complexity of tasks explains why some tasks are more demanding for one individual, but less demanding for another (Robinson, 2001); therefore, task difficulty might indicate, and justify the existence of, individual differences among learners (Albert \& Kormos, 2011). As a case in point, affective individual variables have been found to explain variances in learners' performance on tasks (Dornyei \& Kormos, 2000). Be that as it may, one might argue that individual differences have differential roles in learners' performance on different types of tasks.

In the present study, we have thus made attempts at examining this potential by exploring the role of critical thinking in learners' performance of written argumentative and narrative tasks. One of the domains wherein critical thinking might open up a relevant line of investigation is the argumentative genre because argumentation is both cognitively-demanding and a typical form of academic writing. As far as justifying the role of critical thinking is concerned, argumentative written tasks, which demand that learners develop their own argument by bringing forth the relevant pieces of evidence as well as to assess arguments put forward by other people, seem to be quite relevant. This relationship will be compared and contrasted with that of narrative written tasks which, as a less cognitively demanding task type, typically offer some sort of visual stimuli and demand that the learner reconstruct a story in written form. 


\subsection{Defining Notions of Complexity, Accuracy, and Fluency (CAF)}

In their attempts to find out the underlying constituents of L2 proficiency and performance, many scholars refer to (a) complexity, (b) accuracy and (c) fluency as three major dimensions (Ellis, 2008; Ellis \& Yuan, 2004; Housen \& Kuiken, 2009; Larsen-Freeman, 2009; Norris \& Ortega, 2009; Skehan, 1998, 2009). Complexity, as defined by Ellis (2003), refers to "the extent to which the language produced in performing a task is elaborate and varied" (p. 340); it also pertains to the degree to which learners are willing to take risks to use the cutting edge of their linguistic knowledge which can finally result in the process of restructuring (Ellis \& Barkhuizen, 2005). Accuracy, on the other hand, bears upon the degree of divergence from a particular norm which can be conceived of as errors (Wolfe-Quintero et al., 1998). Moreover, fluency relates to learners' general language proficiency, typified by impressions of ease, expressiveness, and smoothness in speech or writing (Chambers, 1997; Freed, 2000; Hilton, 2008).

\subsection{Purpose of the Study}

The number of studies on critical thinking shows its crucial status in language learning and the various ways through which this key concept can be explored. Simply put, considering the fact that in an argumentative task, as befits the term, learners are generally required either to construct their own argument by providing adequate and relevant evidence or to evaluate someone else's argument by considering its claims and assessing the respective evidence and that a narrative task, by virtue of its open-ended nature, demands that learners recite a fictional or real account of an event or an experience sequentially (Justice, Bowles, Pence, \& Gosse, 2010), these task types seem to smooth the way for learners to use their critical thinking ability; in the light of this corollary, it was found markedly pertinent to establish the role of critical thinking. The study reported in this article, therefore, aimed to examine the role of critical thinking in upper-intermediate EFL learners' performance on two particular task types, i.e. the argumentative and narrative tasks, while controlling for the differences in the participants' level of proficiency. Therefore, in this study we attempt to answer the following two questions:

A. Does critical thinking have any role in the CAF of upper-intermediate EFL learners' argumentative writings?

B. Does critical thinking have any role in the CAF of upper-intermediate EFL learners' narrative writings?

\section{Method}

\subsection{Participants}

The participant of the present study comprised 70 male and female upper-intermediate learners majoring in English Language and Literature in University of Isfahan, Iran voluntarily took part in the study. Their ages ranged from 18 to 26. Based on a version of an Oxford Placement Test (OPT), upper-intermediate-level learners were selected for the study. The test contained 60 multiple choice items, and it was used to enable the researchers to control the language proficiency of the learners. This test consisted of grammar (20 items), vocabulary (20 items), reading comprehension (20 items) together with a writing section. The allotted time for answering the questions was 45 minutes. After correcting the papers, 70 learners were selected as the upper-intermediate group based on the OPT manual.

\subsection{Measurement Tools}

\subsubsection{Watson-Glaser Critical Thinking Appraisal}

Firstly, the Persian version of Watson-Glaser Critical Thinking Appraisal, Form A (WGCTA-FA) was used 
for measuring critical thinking. The test encompasses five subsections, namely drawing inferences, recognizing assumptions, making deductions, interpreting evidence, and evaluating arguments, each comprising 16 items with two to five alternatives. The appraisal is not subject-specific and can be completed in 60 minutes. The test-retest reliability of the original appraisal $(r=0.81)$ has been reported by Watson and Glaser $(1980)$, and the reliability coefficient of its Persian adaptation has been estimated by Cronbach's Alpha $(\alpha=0.85)$ in Faravani (2006). A composite score for the five subscales of the test is obtained with values varying from 0 to 80 . In the present study, Cronbach Alpha estimated the reliability of the whole items as 0.79 .

\subsubsection{Tasks}

\subsubsection{Written Argumentative Task}

The first group of learners $(n=36)$ were asked to write an argumentative essay giving their opinions concerning the effect of technology on human's life. They were asked to present evidence and support their own positions on the issue on an assignment sheet. A written argumentative task was chosen because argumentation is a cognitively-demanding task and is commonly used for academic writings.

\subsubsection{Written Narrative Task}

The second group of learners $(n=34)$ were assigned a narrative task. The narrative task involved learners in narrating a story based on a number of pictures, as visual cues, in the form of a cartoon strip. Thirty minutes was accordingly allotted to the activity. A written narrative task was chosen, as this task type seemed to easily lend itself to eliciting the thought processes of learners. To measure reliability, two raters were asked to score the learners' writings.

It is worth noting that the reliability of these measures was determined by two trained raters who coded the data for the all the learners in each group. Reliability was determined by looking at the percentage of agreement between the raters. An inter-rater reliability check on the two raters was calculated on each of the rating categories and yielded coefficients ranging from 0.66 to 0.81 .

\subsubsection{Measures of Task Performance}

Considering the fact that "a full picture of language development in L2 writing can only be obtained by engaging fluency, accuracy, and complexity measures at various linguistic levels" (Lu, 2011, p. 38), measures of Complexity, Accuracy and Fluency (CAF) were used in the present study to assess the quality of learners' written productions. In order to conduct this analysis, all written outputs were firstly coded for T-units and clauses. A T-unit is characterized as "one main clause plus whatever subordinate clauses happen to be attached to or embedded within it" (Hunt, 1966, p. 735). For the measurement of complexity and accuracy, the writings had to be analyzed for clauses wherein independent and dependent clauses were distinguished. In the present study, dependent clauses were those which comprised a finite or a non-finite verb and at least one additional clause element such as subject, object, complement or adverbial.

$>$ Complexity: A number of measures have been employed to operationalize the construct of syntactic complexity in both oral and written data. In an historical overview, Norris and Ortega (2009) have stipulated three measureable sub-constructs in syntactic complexity, namely complexity in terms of subordination, general complexity, and sub-clausal complexity characterized as phrasal elaboration. It is generally acknowledged that coordination can show complexity at beginning levels of L2 development, subordination is a powerful index of complexity at intermediate and upper-intermediate levels, and sub-clausal complexity has a better predictive power when measuring syntactic complexity at advanced levels. Since the participants of this study were at the upper-intermediate level of proficiency, we took it for granted that subordination measures would be the most reliable indicator of syntactic complexity. Complexity was therefore measured in this study through calculating the proportion of clauses to T-units, which according to Foster and Skehan (1996) is a reliable measure of subordination correlating well with 
Argumentative and narrative written task performance: Differential effects of critical thinking

other complexity measures. Besides, the T-unit can be ideal for intermediate or advanced written data which are typically formed in full clauses and sentences (Norris \& Ortega, 2009). Still another measure of complexity used in the present study is the proportion of dependent clauses to clauses (DC/C), which investigates the degree of embedding in the text (Wolfe-Quintero, Inagaki, \& Kim, 1998).

$>$ Accuracy: Unlike complexity and fluency, measures of accuracy are more agreed-upon among researchers (Tavakoli \& Skehan, 2005). In the present study, two general measures of accuracy were used as percentages: the proportion of error-free T-units to all T-units (EFT/T) and the proportion of error-free clauses to all clauses (EFC/C). Moreover, errors were either errors of syntax such as errors in word order and missing elements or errors of morphology such as errors in use of articles and prepositions, verb tense, subject-verb agreement and errors in word forms.

$>$ Fluency: To estimate learners' fluency in writing, L2 writing researchers have used various measures to date: syllables per minute and number of dysfluencies (Ellis \& Yuan, 2004); mean number of words per minute (Ong \& Zhang, 2011); average number of words per T-unit (Larsen-Freeman, 2006) number of words, T-units and clauses per text (Wigglesworth \& Storch, 2009). In the current study, following Wigglesworth and Storch, fluency was appraised with regards to the average number of words, T-units and clauses per text.

\section{Results}

\subsection{Critical Thinking and Narrative Task Performance}

A Pearson product-moment correlation coefficient was computed to assess the relationship between critical thinking and the CAF of narrative task performance. As shown in Table 1, error free clauses $(r=-.411, p<0.05)$ and error free T-units $(r=-.469, p<0.05)$, as two indicators of learners' performance accuracy, were negatively correlated with the drawing inferences. However, there was found no significant relationship between other subscales of WGCTA and the CAF of learners' narrative written task performance.

\section{Table 1}

Correlations between critical thinking and narrative task performance $(n=34)$

\begin{tabular}{|c|c|c|c|c|c|}
\hline Narrative task & $\begin{array}{l}\text { Drawing } \\
\text { inferences }\end{array}$ & $\begin{array}{l}\text { Recognizing } \\
\text { assumptions }\end{array}$ & $\begin{array}{c}\text { Making } \\
\text { deductions }\end{array}$ & $\begin{array}{c}\text { Interpreting } \\
\text { evidence }\end{array}$ & $\begin{array}{l}\text { Evaluating } \\
\text { arguments }\end{array}$ \\
\hline NO of Words & .253 & .183 & .340 & .165 & .082 \\
\hline NO of T-units & .133 & .087 & .299 & .118 & .150 \\
\hline NO of Clauses & .267 & .230 & .203 & .183 & .212 \\
\hline $\begin{array}{l}\text { Clauses per } \\
\text { T-unit }\end{array}$ & .214 & .219 & .322 & .375 & .415 \\
\hline $\begin{array}{l}\text { Dep. Clauses } \\
\text { Percentage }\end{array}$ & .295 & .117 & .126 & .147 & .287 \\
\hline $\begin{array}{l}\text { Error Free } \\
\text { Clauses } \\
\text { Percentage }\end{array}$ & $-.411 *$ & .183 & .066 & .134 & .226 \\
\hline $\begin{array}{l}\text { Error Free } \\
\text { T-units } \\
\text { Percentage }\end{array}$ & $-.469 *$ & .230 & .277 & .160 & .357 \\
\hline
\end{tabular}

\subsection{Critical Thinking and Argumentative Task Performance}

The correlation analysis reported in Table 2 shows negative relationships between the three measures of argumentative task fluency and students' score on the Drawing Inferences subscale (number of words $r=-.359$, $p<0.05$; number of T-units $r=-.452, p<0.05$; number of clauses $r=-.494, p<0.05$ ). Moreover, critical 
Dabaghi, A., Zabihi, R., \& Rezazadeh, M.

thinking proved to have a more prominent role to play in the complexity scores of learners' task performance. Results with regard to complexity measures, illustrated in Table 2, reveal that the syntactic complexity of argumentations produced was affected by Making Deductions (Clauses per T-unit $r=.534, p<0.05$; Dep. Clauses Percentage $r=.651, p<0.05$ ), Interpreting Evidence (Clauses per T-unit $r=.612, p<0.05$; Dep. Clauses Percentage $r=.563, p<0.05$ ), and Evaluating Arguments (Clauses per T-unit $r=.394, p<0.05$; Dep. Clauses Percentage $r=.443, p<0.05$ ). Nonetheless, there was no significant correlation between complexity and Drawing Inferences and Recognizing Assumptions subscales. Finally, with regards to the accuracy of the performances, it was found that only Recognizing Assumptions had a significant, but negative, relationship with Error Free Clauses Percentage $(r=-.448, p<0.05)$ and Error Free T-units Percentage $(r=-.379, p<0.05)$.

\section{Table 2}

Correlations between critical thinking and argumentative task performance $(n=36)$

\begin{tabular}{|c|c|c|c|c|c|}
\hline $\begin{array}{c}\text { Argumentative } \\
\text { task }\end{array}$ & $\begin{array}{l}\text { Drawing } \\
\text { inferences }\end{array}$ & $\begin{array}{l}\text { Recognizing } \\
\text { assumptions }\end{array}$ & $\begin{array}{c}\text { Making } \\
\text { deductions }\end{array}$ & $\begin{array}{l}\text { Interpreting } \\
\text { evidence }\end{array}$ & $\begin{array}{l}\text { Evaluating } \\
\text { arguments }\end{array}$ \\
\hline NO of Words & $-.359 *$ & .245 & .110 & .258 & .251 \\
\hline $\mathrm{NO}$ of $\mathrm{T}$-units & $-.452 *$ & .295 & .027 & .372 & .125 \\
\hline NO of Clauses & $-.494 *$ & .295 & .047 & .100 & .121 \\
\hline $\begin{array}{l}\text { Clauses per } \\
\text { T-unit }\end{array}$ & .244 & .273 & $.534 *$ & $.612 *$ & $.394 *$ \\
\hline $\begin{array}{l}\text { Dep. Clauses } \\
\text { Percentage }\end{array}$ & .246 & .245 & $.651 *$ & $.563 *$ & $.443 *$ \\
\hline $\begin{array}{l}\text { Error Free } \\
\text { Clauses } \\
\text { Percentage }\end{array}$ & .175 & $-.448^{*}$ & .321 & .011 & .387 \\
\hline $\begin{array}{l}\text { Error Free } \\
\text { T-units } \\
\text { Percentage }\end{array}$ & .099 & $-.379 *$ & .052 & .212 & .092 \\
\hline
\end{tabular}

Note. * Correlation is significant at the 0.05 level.

\section{Discussion and Conclusion}

If we take into account the significant correlations between critical thinking and measures of narrative task performance that are identified in this study (Tables 1), the ability of accuracy appears to make the most pronounced association in that two accuracy measures of narrative task performance (i.e. error free clauses and error free T-units) were found to negatively correlate with Drawing Inferences. This subscale comprises a number of sub-skills such as, inter alia, the ability to arrive at conclusions, the ability to evaluate the validity of inferences that logically follow from the available evidence, the ability to evaluate all relevant information before drawing a conclusion, the ability to judge the plausibility of different conclusions, the ability to select the most appropriate conclusion, and the ability to avoid overgeneralization beyond the evidence (Watson \& Glaser, 1980).

The results of this study displayed how learners' ability to evaluate the validity of inferences drawn from a series of factual statements negatively affected their accurate narrative productions. This finding is justifiable enough considering the fact that the narrative task involved learners in narrating a story based on only a picture as a visual cue; this in turn requires that learners draw relevant inferences from different parts of the picture and apply their conclusions in writing the narrative. Lack of accuracy may be due to the fact that all these thought processes could have occupied a considerable load in the learners' minds, making them unable to produce accurate written language. On the other hand, when it came to the argumentative task, the correlation analysis showed negative relationships between the three measures of argumentative task fluency and students' score on the Drawing Inferences subscale. Again, it can be argued that lack of fluency on the part of language learners can be attributed to the fact that the number of thought processes which learners have undergone could have taken a lot of their performance time so that they have been unable to produce fluent productions.

Furthermore, results of the complexity measures revealed that the syntactic complexity of produced 
Argumentative and narrative written task performance: Differential effects of critical thinking

argumentations was affected by learners' ability to make deductions, interpreting evidence, and evaluating arguments: (i) making deductions include abilities such as the ability to move from theory to observations or findings, the ability to create a specific conclusion from a generalization, and the ability to properly identify the members of a class of things at issue; (ii) interpreting evidence encompasses the ability to distinguish between strong and weak arguments and the ability to distinguish between relevant and irrelevant arguments; (iii) evaluating arguments comprise abilities like the ability to analyze arguments objectively and accurately, the ability to determine whether to believe arguments or act accordingly, the ability to overcome a confirmation bias, and the ability to control emotions (Watson \& Glaser, 2006).

This finding lends enough support to the claim that critical thinking is not an indivisible construct but comprises several independent elements (Shipman, 1983; Ross \& Ross, 1976; Fraser, 1980; Sternberg \& Baron, 1985; Wagner \& Harvey, 2003; Watson \& Glaser, 1980, 2006) as only some measures of critical thinking such as making deductions, interpreting evidence, and evaluating arguments were found to be relevant to learners' complex performances on the argumentative written task. Unlike the argumentative task, however, these dimensions of critical thinking were not found to bear any relationship with measures of the narrative task. Such a general conclusion is justifiable in the sense that the argumentative task used in the present study was so cognitively demanding and complex that has caused the complexity subscale of the WGCTA to have the greatest impact. In general, the results obtained concerning the interface between critical thinking and measures of written task performance may contribute to making pedagogical decisions and can make materials developers, syllabus designers and language teachers revisit the selection and implementation of language teaching tasks. Accordingly, the professionals in the field of materials development ought to include definitive tasks in the textbooks with the purpose of enhancing learners' critical thinking. To give but one example, they may opt for including tasks which demand a considerable degree of recognition, evaluation and argumentation.

In the meantime, language teachers may choose to develop programs to raise the consciousness of language learners in being and becoming a critical thinker. By and large, there is hope and cause for being optimistic, as signs emerge that outlooks on language teaching may be changing. It seems that by reallocating the role of teachers from language teachers to educational language teachers (Pishghadam, Zabihi, \& Kermanshahi, 2012) there is hope for future language education. For this to happen, confident professionals who are able not only to acquire complete knowledge of language teaching but also to acquire sufficient knowledge of other disciplines are required. Some recommendations from the research reported in this study can be summarized as follows: (i) ELT professionals should recognize the necessity of explicit teaching of critical thinking in language classes and pave the way for the incorporation of critical thinking courses in to the whole ELT curriculum; (ii) English practitioners should introduce, and be introduced to, the specific techniques and materials that facilitate the enhancement learners' critical thinking abilities; and (iii) there should be partnerships between language teachers and psychologists of education to figure out the 'what' and 'how' of critical thinking practices that ELT classes can provide.

\section{References:}

Albert, A., \& Kormos, J. (2011). Creativity and narrative task performance: An exploratory study. Language Learning, 61, 73-99. <http://dx.doi.org/10.1111/j.1467-9922.2011.00643.x >

Azar, A. (2010). The effect of critical thinking dispositions on students' achievement in selection and placement exam for university in Turkey. Journal of Turkish Science Education, 7(1), 61-73.

Birjandi, P., \& Bagherkazemi, M. (2010). The relationship between Iranian EFL teachers' critical thinking ability and their professional success. English Language Teaching, 3(2), 135-145.

Canagarajah, A. S. (1999). Resisting linguistic imperialism in English teaching. Oxford: Oxford University.

Chaffee, J. (1988). Thinking critically. Boston, MA, Houghton Mifflin.

Chambers, F. (1997). What do we mean by oral fluency? System, 25, 535-544.

$<$ http://dx.doi.org/10.1016/S0346-251X(97)00046-8>

Conard, M. A. (2006). Aptitude is not enough: How personality and behavior predict academic performance. 
Dabaghi, A., Zabihi, R., \& Rezazadeh, M.

Journal of Research in Personality, 40, 339-346. <http://dx.doi.org/10.1016/j.jrp.2004.10.003>

Dewey, J. (1916). Democracy and education: An introduction to the philosophy of education. New York: Macmillan.

Dewey, J. (1933). How we think: A restatement of the relation of reflective thinking to the educative process. Boston: D.C. Heath.

Dornyei, Z., \& Kormos, J. (2000). The role of individual and social variables in oral task performance. Language Teaching Research, 4, 275-300.

Ellis, R. (2008). The study of second language acquisition. Oxford: Oxford University Press.

Ellis, R., \& Barkhuizen, G. (2005). Analyzing learner language. Oxford: Oxford University Press.

Ellis, R., \& Yuan, F. (2004). The effects of planning on fluency, complexity, and accuracy in second language narrative writing. Studies in Second Language Acquisition, 26(1), 59-84.

$<$ http://dx.doi.org/10.1017/S0272263104261034>

Ennis, R. H., \& Millman, J. (1985). Cornell Critical Thinking Test-Level X. Pacific Grove, CA: Midwest Publications.

Ennis, R. H., \& Weir, E. (1985). The Ennis-Weir essay test: An instrument for testing and teaching. Midwest Publications: Pacific Grove, CA.

Fahim, M., Bagherkazemi, M., \& Alemi, M. (2010). The relationship between test takers critical thinking ability and their performance on the reading section of TOEFL. Journal of Language Teaching and Research, 1(6), 830-837. <http://dx.doi.org/10.4304/jlttr.1.6.830-837>

Faravani. (2006). Portfolio and critical thinking. Unpublished Masteral thesis, Ferdowsi University of Mashhad, Iran.

Farsides, T., \& Woodfield, R. (2003). Individual differences and undergraduate academic success: The roles of personality, intelligence, and application. Personality and Individual Differences, 34, 1225-1243. $<$ http://dx.doi.org/10.1016/S0191-8869(02)00111-3>

Facione, P. (1990a). The California Critical Thinking Skills Test-college level technical report 1: Experimental validation and content validity. California Academic Press, Millbrae, CA.

Facione, P. (1990b). The California Critical Thinking Skills Test-college level technical report 2: Factors predictive of critical thinking skills. California Academic Press, Millbrae, CA.

Facione, P. (2006). Critical thinking: What it is and why it counts. California: California Academic Press.

Foster, P., \& Skehan, P. (1996). The influence of planning and task type on second language performance. Studies in Second Language Acquisition, 18, 299-323. <http://dx.doi.org/10.1017/S0272263100015047>

Fraser, B. J. (1980). Development and validation of a test of enquiry skills. Journal of Research in Science Teaching, 17, 7-16. <http://dx.doi.org/10.1002/tea.3660170103>

Freed, B. (2000). Is fluency, like beauty, the eyes, of the beholder? In H. Riggenbach (Ed.), Perspectives on fluency. The University of Michigan Press.

Freeley, A. J., \& Steinberg, D.L. (2000). Argumentation and debate: Critical thinking for reasoned decision making (10th ed.). Wadsworth: Thomson Learning.

Freire, P. (1970). Pedagogy of the oppressed. New York: The Seabury Press.

Gatto, J. (2001). The seven-lesson schoolteacher, rereading America: Cultural contexts for critical thinking and writing. Boston, MA.

Frisby, C. L. (1992). Construct validity and psychometric properties of the Cornell Critical Thinking Test (Level Z): A contrasted group analysis. Psychological Reports, 71, 291-303.

Gadzella, B. M., \& Baloglu, M. (2003). Psychometric properties of Watson-Glaser Critical Thinking Appraisal for a sample of education majors. Psychology Report, 92(3), 1249-1254.

$<$ http://dx.doi.org/10.2466/PR0.92.3.1249-1254>

Ghaemi, H., \& Taherian, R. (2011). The role of critical thinking in EFL teachers' teaching success. MJAL, 3(1), $8-22$.

Giancarlo, C. A., \& Facione, P. A. (2001). A Look across four years at the disposition toward critical thinking among undergraduate students. The Journal of General Education, 50(1), 29-55. $<$ http://dx.doi.org/10.1353/jge.2001.0004> 
Argumentative and narrative written task performance: Differential effects of critical thinking

Hilton, H. (2008). The link between vocabulary knowledge and spoken L2 Fuency. Language Learning Journal, 36(2), 153-166. <http://dx.doi.org/10.1080/09571730802389983>

Housen, A., \& Kuiken, F. (2009). Complexity, accuracy, and fluency in second language acquisition. Applied Linguistics, 30(4), 461-473. <http://dx.doi.org/10.1093/applin/amp048>

Hunt, K. (1966). Recent measures in syntactic development. Elementary English, 43, 732-739.

Jacobs, S. S. (1995). Technical characteristics and some correlates of the California critical thinking skills test forms A and B. Higher Education Research, 36, 89-108. <http://dx.doi.org/10.1007/BF02207768>

Justice, L. M., Bowles, R., Pence, K., \& Gosse, C. (2010).A scalable tool for assessing children's language abilities within a narrative context The NAP (Narrative Assessment Protocol). Early Childhood Research Quarterly, 25, 218-234. <http://dx.doi.org/10.1016/j.ecresq.2009.11.002>>

King, P. M., Wood, P. K., \& Mines, R. A. (1990). Critical thinking among college and graduate students. Review of Higher Education, 13(3), 167-186.

Kokinda, M. A. (1989). The measurement of critical thinking skills in a selected baccalaureate nursing program. Dissertations available from ProQuest. Paper AAI9004798. Available from http://repository.upenn.edu/dissertations/AAI9004798

Labby, S., Lunenburg, F. C., \& Slate, J. R. (2012). Emotional intelligence and academic success: A conceptual analysis of educational leaders. International journal of Educational Leadership Preparation, 7(1), 1-11.

Laidra, K., Pullmann, H., \& Allik, J. (2007). Personality and intelligence as predictors of academic achievement: A cross-sectional study from elementary to secondary school. Personality and Individual Differences, 42(3), 441-451. <http://dx.doi.org/10.1016/j.paid.2006.08.001>

Larsen-Freeman, D. (2009). Adjusting expectations: The study of complexity, accuracy, and fluency in second language acquisition. Applied Linguistics, 30(4), 579-589. <http://dx.doi.org/10.1093/applin/amp043>

Loftspring, R.G. (2006). The relationship of years of experience and level of education to critical thinking skills of physical therapists. Unpublished Doctoral dissertation, University of Cincinnati.

Lu, X. (2011). A Corpus-Based Evaluation of Syntactic Complexity Measures as Indices of College-Level ESL Writers' Language Development. Tesol Quarterly, 45(1), 36-62. <http://dx.doi.org/10.5054/tq.2011.240859>

McKown, L. K. (1997). Improving leadership through better decision making: Fostering critical thinking. A research paper presented to the Research Department of Air Command and Staff College. Retrieved from http://www.au.af.mil/au/awc/awcgate/acsc/97-0506.pdf

McCutcheon, L. E., Apperson, J. M., Hanson, E., \& Wynn, V. (1992). Relationships among critical thinking skills, academic achievement, and misconceptions about psychology. Psychological Reports, 71, 635-639.

Mines, R. A., King, P. M., Hood, A. B., \& Wood, P. K. (1990). Stages of intellectual development and associated critical thinking skills in college students. Journal of College Students Developments, 31, 537-547.

Naderi, H., Abdullah, R., Aizan, H. T., Sharir, J., \& Kumar, V. (2009). Creativity, age and gender as predictors on academic achievement among undergraduate students. Journal of American Science, 5(5), 101-112.

Nelson, C. E. (1994). Critical thinking and collaborative learning: in K. Boswald, S. J. Hamilton (eds.) Collaborative learning: Underlying processes and effective techniques. New directions for teaching and learning \#59: Jossey Bass Higher Education and Adult Education Series: San Francisco, CA.

Norris, S. P., \& Ennis, R. H. (1989). Evaluating critical thinking. Pacific Grove, CA: Midwest.

Norris, S. P., \& King, R. (1984). The design of a critical thinking test on appraising observations. Institute for Educational Research and Development, Memorial University of Newfoundland, Newfoundland.

Norris, J. M., \& Ortega, L. (2009). Towards an organic approach to investigating CAF in instructed SLA: The case of complexity. Applied Linguistics, 30(4), 555-578. <http://dx.doi.org/10.1093/applin/amp044>

Norton, B., \& Toohey, K. (2004). Critical pedagogies and language learning. Cambridge: Cambridge University Press.

Ong, J., \& Zhang, L. J. (2011). Effects of task complexity on the fluency and lexical complexity in EFL students' argumentative writing. Journal of Second Language Writing, 19(4), 218-233. 
Dabaghi, A., Zabihi, R., \& Rezazadeh, M.

$<$ http://dx.doi.org/10.1016/j.jslw.2010.10.003>

Parker, J. D. A., Summerfeldt, L. J., Hogan, M. J., \& Majeski, S. A. (2004). Emotional intelligence and academic success: Examining the transition from high school to university. Personality and Individual Differences, 36, 163-172. <http://dx.doi.org/10.1016/S0191-8869(03)00076-X>

Pennycook, A. (1999). Introduction: Critical approaches to TESOL. TESOL Quarterly, 33 (3), 329-348. $<$ http://dx.doi.org/10.2307/3587668>

Pennycook, A. (2001). Critical applied linguistics: A critical introduction. Mahwah, NJ: Lawrence Erlbaum Associates.

Pica, T., Kanagy, R., \& Falodun, J. (1993). Choosing and using communication tasks for second language instruction and research. In G. Crookes \& S. Gass (Eds.), Tasks and language learning: Integrating theory and practice (pp. 9-34). Clevedon, England: Multilingual Matters.

Pishghadam, R., \& Zabihi, R. (2012). Life syllabus: A new research agenda in English language teaching. TESOL Arabia Perspectives, 19(1), 23-27.

Pishghadam, R., Zabihi, R., \& Kermanshahi, P. (2012). Educational language teaching: A new movement beyond reflective/critical teacher. Life Science Journal, 9(1), 892-899.

Pithers, R. T., \& Soden, R. (2000). Critical thinking in education: A review. Educational Research, 42 (3), 237-249.

Ramanathan, V. (2002). The politics of TESOL education. New York: Routledge Falmer/Taylor \& Francis.

Robinson, P. (2001). Task complexity, task difficulty, and task production: Exploring interaction in a componential framework. Applied Linguistics, 22, 27-57. <http://dx.doi.org/10.1093/applin/22.1.27>

Ross, J. D., \& Ross, C. M. (1976). Ross test of higher cognitive processes. Novato, CA: Academic Therapy Publications.

Shipman, V.C. (1983). The New Jersey test of reasoning skills. Totowa, N.J: Slosson.

Skehan, P. (1996). A framework for the implementation of task based instruction. Applied Linguistics, 17, 38-62. $<$ http://dx.doi.org/10.1093/applin/17.1.38>

Skehan, P. (1998). A cognitive approach to language learning. Oxford: Oxford University Press.

Skehan, P. (2009). Modeling second language performance: Integrating complexity, accuracy, fluency, and lexis. Applied Linguistics, 30(4), 510-532. <http://dx.doi.org/10.1093/applin/amp047>

Sternberg, R.J., \& Baron, J. B. (1985). A statewide approach to measuring critical thinking skills. Educational Leadership, 43, 40-43.

Tsui, L. (2002). Fostering critical thinking through effective pedagogy: Evidence from four institutional case studies. The Journal of Higher Education, 73(6), 740-763. <http://dx.doi.org/10.1353/jhe.2002.0056>

Villavicencio, F. T. (2011). Critical thinking, negative academic emotions, and achievement: A meditational analysis. The Asia-Pacific Education Researcher, 20(1), 118-126.

Wagner, T. A., \& Harvey, R. J. (2003). Developing a new critical thinking test using item response theory. Paper presented at the 2003 annual conference of the Society for Industrial and Organizational Psychology. Retrieved June 11, 2008, from http://harvey.psyc.vt.edu/Documents/WagnerHarveySIOP2003.pdf

Watson, G. B., \& Glaser, E. M. (1980). WGCTA Watson-Glaser critical thinking appraisal manual: Forms A and B. San Antonio: The Psychological Corporation.

Watson, G., \& Glaser, E. M. (2006). Watson-Glaser critical thinking appraisal short form manual. San Antonio, TX: Harcourt.

Wigglesworth, G., \& Storch, N. (2009). Pair versus individual writing: Effects on fluency, complexity and accuracy. Language Testing, 26(3) 445-466. <http://dx.doi.org/10.1177/0265532209104670>

Willis, D., \& Willis, J. (1996). Consciousness raising activities in the language classroom. In J. Willis \& D. Willis (Eds.), Challenge and change in language teaching (pp. 63-76). London: Heinemann.

Wolfe-Quintero, K., Inagaki, S., \& Kim, H. Y. (1998). Second language development in writing: Measures of fluency, accuracy, and complexity. Hawaii: University of Hawaii, Second Language Teaching and Curriculum Center.

Yeh, Y., \& Wu, J. (1992). The relationship between critical thinking and academic achievement among elementary and secondary school students. Journal of Education and Psychology, 15, 79-100. 